\title{
臨床実習における教育方法に関する一考察 \\ ——指導者の理想像アンケート調査より——

\author{
Discussing Methods of Education during Clinical Training: Results of a Questionnaire \\ Survey on Views of an Ideal Supervisor
}

吉村 修 ${ }^{1)}$ 二宮 省悟 ${ }^{2)}$ 楠元 正順 ${ }^{1)} \quad$ 吉田 勇一 2) 演田 輝一 2)

OSAMU YOSHIMURA, RPT ${ }^{1)}$, SHOGo NINOMIYA, RPT, $\mathrm{PhD}^{2)}$, MASAZUMI KUSUMOTO, RPT ${ }^{1)}$, YUICHI YOSHIDA, RPT ${ }^{2)}$, TERUKAZU HAMADA, RPT ${ }^{2)}$

${ }^{1)}$ Kawasaki Hospital: 538 Tsunoe, Yame-shi, Fukuoka 834-0024, Japan TEL +81 943-23-3351 E-mail: osayoshi036@gmail.com

${ }^{2)}$ Department of Physical Therapy, Faculty of Nursing and Welfare, Kyushu University of Nursing and Social Welfare

Rigakuryoho Kagaku 33(4): 587-590, 2018. Submitted Jan. 19, 2018. Accepted Mar. 8, 2018.

\begin{abstract}
Purpose] With the aim of improving physical therapist education, clinical training supervisors' views of an ideal supervisor and differences in such views related to the length of clinical experience were examined. [Subjects and Methods] A questionnaire survey was conducted, asking physical therapists working in 42 facilities to voluntarily respond. [Results] The 5 most frequent words were "student", "supervision", "can", "training", and "ability". Furthermore, responses were classified into 3 clusters: <conveying the enjoyment of clinical practice>, $<$ being able to supervise students according to their abilities $>$, and $<$ considering appropriate approaches for individual patients together $>$. When focusing on the length of clinical experience, differences were observed in 5 words: "student", "thinking", "enjoyable", "according", and "together". [Conclusion] Clarifying and understanding views of an ideal supervisor may contribute to the improvement of physical therapist education. This may also be needed to enhance physical therapists' qualities.
\end{abstract}

Key words: physical therapist education, clinical training supervisors, views of an ideal supervisor

要旨：〔目的〕より良い理学療法士教育の構築を目指して, 臨床実習指導者（以下，指導者）が考える指導者の理想 像および臨床経験年数での理想像の違いの有無の把握を目的とした。〔対象と方法〕 42 施設の理学療法士を対象とし, 任意に回答要請し, 質問紙調査を行った。〔結果〕上位 5 番目までの頻出語が「学生」,「指導」,「できる」,「実習」,「能力」 であった「臨床の楽しさを伝える」,「能力に合わせた学生指導ができる」,「患者のことを一緒に考える」の 3 つの クラスターに分類された。 臨床経験年数での違いは, 「学生」,「考える」,「楽しい」, 「合わせる」,「一緒」の 5 語で 差を認めた。〔結語〕指導者の理想像を検討して理解することは, より良い理学療法士教育に役立ち, 理学療法士の 質の向上に必要であると考える.

キーワード : 理学療法教育, 臨床実習指導者, 理想像

\footnotetext{
1) 医療法人社団慶仁会川㠃病院：福岡県八女市津江 538 ( ( 834-0024) TEL 0943-23-3351

2) 九州看護福祉大学 看護福祉学部 リハビリテーション学科 


\section{I.はじめに}

臨床実習は，実際の症例と現場に関わることで養成施 設で習得した知識や技術，医療専門職としての態度を合 わせた総合的実践力を養うものである。近年, 理学療法 士数の急激な増加掞よび理学療法士の質の低下が懸念さ れている ${ }^{1,2}$. 全国の入学定員数が 1 万 3 千人を超え, 臨床実習施設や臨床実習指導者（以下, 指導者）の確保 も急務といえる。この状況下, 臨床経験が少ないまま指 導者を担うこともあり，指導者自身が学生時代に受けた 臨床実習指導や職場内での経験に基づく指導を行うこと も多い。柴田 ${ }^{3)}$ は今の学生は, 以前のように明確な目 的意識を持った者ばかりでないと述べている.

日本理学療法士協会は，養成校数の激増に加え，これ までの専門学校養成以外に学士取得を目標とする大学で の課程設置が増えてきたことも影響し，これまで以上に 学生の学力や資質面, そして理学療法学に対する取り組 み姿勢に格差が認められるようになったと指摘し，学生 を画一的な凡例をもとに捉えることはもはや不可能であ り, 学生一人一人を理解していかなければ, 臨床実習教 育は成立しないと述べている ${ }^{11}$ ，理学療法士の質の向上 の取り組みの一つには, 臨床実習に扔ける指導者が行う 学生に対する教育の質の向上が必要と考える. 理学療法 士の卒前教育である臨床実習に扔いて，より良い教育に は理想とする指標や特性を明らかにする必要があると考 える.これまで指導者の理想像について選択肢でなく, 詳細がわかる自由記載を利用した研究は少ない.

本研究の目的は, より良い理学療法士教育の構築を目 指して, 指導者が考える指導者の理想像㧍よび臨床経験 年数での理想像の違いを把握することである。

\section{II. 対象と方法}

\section{1. 対象}

対象は, アンケートにご協力いただいた九州地方の 42 施設（表 1) の理学療法士を対象とした。ヘルシン キ宣言に基づき, 調查対象施設に対して, 口頭抒よび文 書にて研究主旨を十分説明し, 同意を得て調查を行っ た。 な押, 本研究調査は所属の倫理委員会の承認を得て

\section{表 1 調査対象施設の基本属性}

\begin{tabular}{lc}
\hline 施設の形態 & 施設数 \\
\hline 総合病院 & 6 \\
一般病院 (上記以外) 一般病床 & 14 \\
一般病院 (上記以外) 療養型病床 & 8 \\
一般病院 (上記以外) 一般病床, 療養型病床 & 5 \\
その他 & 3 \\
記載なし & 6 \\
\hline
\end{tabular}

行った（承認番号：2000）.

2. 方法

任意に回答要請し，無記名の質問紙調査を行った。調 査期間は平成 25 年 8 月から平成 26 年 3 月までの 8 カ 月間とした。調査については, 各施設のリハビリテー ション部門の代表者へ調査目的，方法を記載した依頼文 書と口頭にて十分説明を行った，回答をもって調査への 同意とした．社会的望ましさ尺度 4)を使用して歪めら れた傾向のある回答を除外する事前処理を行った。設問 内容を「理想とする臨床実習指導者像を具体的にご記入 ください」として，自由記載法にて得られた回答につい て調查・分析を行った。

回答はテキスト形式にデータ化し，樋口らの開発した フリーソフトウェア KH Coder を利用して, テキストマ イニングの手法を用いて, 頻出語抽出扔よび頻出語にお ける性質を把握するために階層クラスター分析（Ward's Method, 出現回数 30 回以上の語を対象）を行った. 臨 床経験年数を $0 \sim 5$ 年目 (A 群), $6 \sim 10$ 年目 (B 群), $11 \sim 15$ 年目 (C 群), 16 年目以上 (D 群) に分類し, 全体での頻出語の出現回数 30 回以上の 13 語を対象とし 各群における頻出語の割合を比較するために $\chi^{2}$ 検定を 行った，期待度数が 0 になるセルがある場合，もしくは 期待度数が 5 未満になるセルが全体の $20 \%$ を超える場 合には，フィッシャーの正確確率検定を実施した。さらら に，有意差を認めた項目には残差分析を行った，統計処 理はR3.3.3を使用し，有意水準 5\%とした。

\section{III. 結 果}

回答数は 790 名, 有効回答数は 689 名 $(87.2 \%)$ であっ た，そのうち，臨床実習指導の経験がある 479 名を分 析対象とした。分析対象には, 臨床経験年数が 3 年未満 でも実習中に学生へのアドバイス経験があると回答した 者も含めた。テキストマイニングにより，全体で 7660 語が抽出された。頻出 150 語を抽出した結果, 上位 5 番目までの頻出語が「学生」,「指導」「「できる」,「実習」, 「能力」であった（表 2).

階層クラスター分析の結果,「臨床の楽しさを伝える」, 「能力に合わせた学生指導ができる」，「患者のことを一 緒に考える」の3つのクラスターに分類された（図 1). 臨床経験年数は A 群 181 名, B 群 164 名, C 群 80 名, $\mathrm{D}$ 群 54 名に分類され, $\chi^{2}$ 検定の結果, 「学生」 $(\mathrm{p}<0.01)$, 「考える」 $(\mathrm{p}<0.01)$ ，「楽しい」 $(\mathrm{p}=0.0187)$,「合わせる」 $(\mathrm{p}<0.01), 「$ 一緒」 $(\mathrm{p}<0.01)$ の 5 語で差を認めた

残差分析の結果, 「学生」は, B 群で有意に少なく, $\mathrm{D}$ 群で有意に多かった。「考える」は，A群で有意に多く， $\mathrm{C}$ 群で有意に少なかった。「楽しい」は，D群で有意に 少なかった． A 群で有意差は認められなかったが比較的 
表 2 頻出語（全体）上位 60 語

\begin{tabular}{|c|c|c|c|c|c|c|c|}
\hline 抽出語 & 出現回数 & 抽出語 & 出現回数 & 抽出語 & 出現回数 & 抽出語 & 出現回数 \\
\hline 学生 & 292 & 考元 & 24 & 行える & 17 & 興味 & 11 \\
\hline 指導 & 223 & 知識 & 24 & コミュニケーション & 16 & 経験 & 11 \\
\hline できる & 67 & 持つ & 23 & 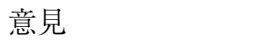 & 16 & 考え方 & 11 \\
\hline 実習 & 64 & 自分 & 23 & 引き出す & 16 & 合う & 10 \\
\hline 能力 & 61 & 行う & 22 & 応じる & 16 & 自身 & 10 \\
\hline 臨床 & 55 & わかる & 22 & 目標 & 16 & 理解 & 10 \\
\hline 患者 & 50 & 治療 & 21 & 説明 & 15 & 感じる & 9 \\
\hline 人 & 49 & 把握 & 21 & 的確 & 14 & 気づく & 9 \\
\hline 伝える & 47 & 技術 & 19 & 社会 & 13 & 姿勢 & 9 \\
\hline 考える & 39 & 適切 & 19 & 理学 & 13 & 責任 & 9 \\
\hline 楽しい & 38 & 評価 & 19 & 療法 & 13 & 必要 & 9 \\
\hline 合わせる & 33 & レベル & 18 & アドバイス & 12 & 押し付ける & 8 \\
\hline 一緒 & 31 & 教える & 18 & 引き出せる & 12 & 見せる & 8 \\
\hline 成長 & 27 & 思う & 18 & 質問 & 12 & 仕事 & 8 \\
\hline 学ぶ & 24 & 導く & 18 & 問題 & 12 & 設定 & 8 \\
\hline
\end{tabular}

高い值を示した $(\mathrm{p}=0.0725)$.「合わせる」は, A 群と $\mathrm{D}$ 群で有意に少なく, $\mathrm{B}$ 群と $\mathrm{C}$ 群で有意に多かった。「一 緒」は, A 群で有意に多く, B 群と D群で有意に少なかっ た。

\section{IV. 考 察}

本研究では, より良い理学療法士教育の構築を目指し て, 指導者が考える指導者の理想像および臨床経験年数 での理想像の違いを把握するため, 調査を行った。今回 の調査の結果, 指導者は, 「臨床の楽しさを伝える指導 者」,「能力に合わせた学生指導ができる指導者」,「患者 のことを一緒に考える指導者」を理想像と考えていた. 日本理学療法士協会も, 指導者の役割として実習学生の 知的好奇心を呼び覚まし, 自己学習を促すよう働きかけ を行うことを重要視しており1)，本研究結果とほぼ同様 の見解を述べている.

「臨床の楽しさを伝える指導者」となるためには，指 導者自身が日々の臨床業務で感じる楽しさを言葉や態度 で伝えることが大切である，また，楽しさを伝えるため には学生の興味を把握することも必要であると考える。 諸橋 ${ }^{5)}$ は学生の強みやよいところを引き出し, 人の成 長を支援することが指導者として大切な資質であり，学 生に面白さや感動場面を演出し, 学生の自己肯定感をよ り高め, その指導過程のなかで学生を成長させ, なおか つ指導者自身も成長できることが望ましいと述べてい る.したがって, 指導者は学生とコミュニケーションを 積極的にとり、学生のモチベーションを高める対応が必 要であると考える.

「能力に合わせた学生指導ができる指導者」となるた めには, 教育者という自覚を持ち, 学生理解を深め, 個

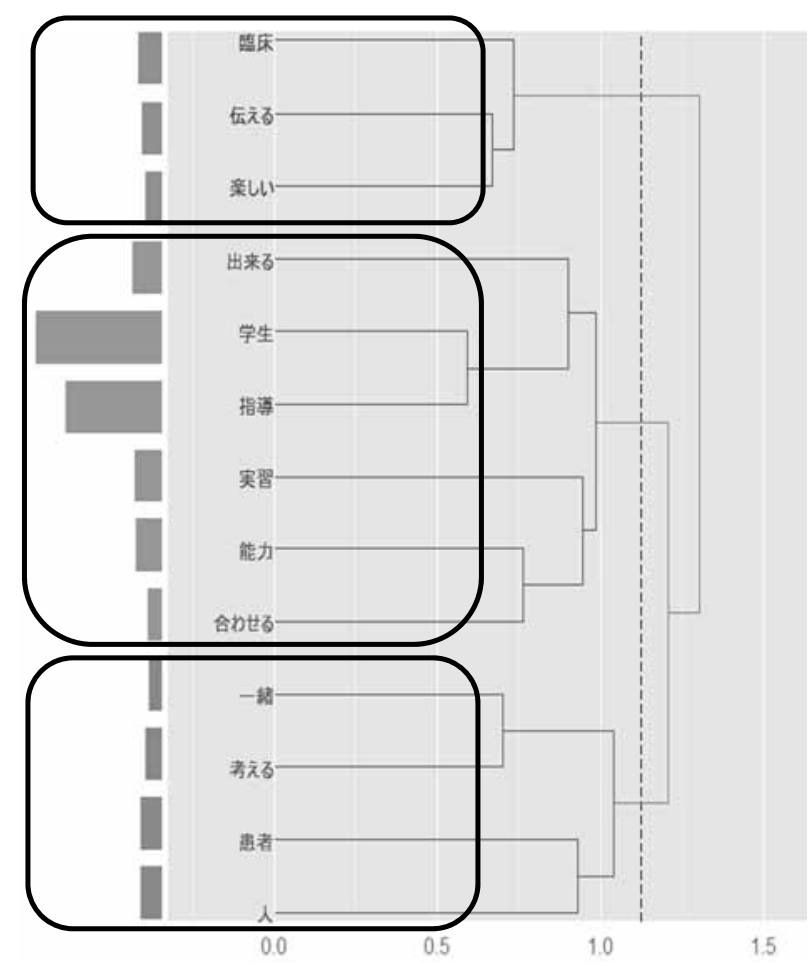

図1 階層クラスター分析

別性を考え学生に合わせた指導を行うことが必要であ る. 教育学的な知識や指導方法に関する知識の修得のた めの学習や研修会などへの参加で指導者としてのスキル の向上に努めることが求められると考える．木村 6) は, 臨床実習の指導のあり方の多くは, 指導者個々の価值観 や経験則に基づいた実習指導として行われているのが実 情のように思われると報告している。また，小林7)は 指導者に共通する課題として, 具体的な指導方法の未確 
表 3 頻出語（臨床経験年数別）上位 15 語

\begin{tabular}{lllll}
\hline & $0 \sim 5$ 年 & $6 \sim 10$ 年 & $11 \sim 15$ 年 & 16 年以上 \\
\hline 1 位 & 学生 & 学生 & 学生 & 学生 \\
2 位 & 指導 & 指導 & 指導 & 指導 \\
3 位 & できる & 能力 & できる & 患者 \\
4 位 & 人 & 実習 & 実習 & できる \\
5 位 & 一緒 & 患者 & 臨床 & 人 \\
6 位 & 考える & 臨床 & 能力 & 実習 \\
7 位 & 楽しい & できる & 伝える & 臨床 \\
8 位 & 実習 & 伝える & 楽しい & 能力 \\
9 位 & 臨床 & 合わせる & 合わせる & 導く \\
10 位 & 伝える & 人 & 患者 & 伝える \\
11 位 & 能力 & 考える & 考え & 治療 \\
12 位 & 患者 & 楽しい & 人 & 一緒 \\
13 位 & 合わせる & 一緒 & 一緒 & 考える \\
14 位 & 考え & 考え & 考える & 楽しい \\
15 位 & 導く & 導く & 導く & 合わせる \\
\hline
\end{tabular}

立や経験則による指導内容を提起しており，経験的な指 導方法に加えて, 教育学的な視点を持ち, 個別性に合わ せた指導が求められると推測された。

「患者のことを一緒に考える指導者」となるためには, 学生がわからないことがあった場合に学生と一緒に考え たり，ヒントを与えたり，または調べる方法を確認しな がら, 問題解決方法を示す必要がある. 日本理学療法士 協会は, 実習中の疑問点を素直に指導者に相談できる環 境作りと，それらを解決すべく教育的・指導的姿勢を もって学生に接することが指導者には必要であると述べ ている1). 奈良 ${ }^{8)}$ は, 学生が実習中に脱落する理由の多 くは指導者との人間関係トラブルであると指摘してい る。さらに，杉本9)は，良好な人間関係を構築してい くためには, 指導者からいま一歩歩み寄った指導が必要 だと報告している。したがって，学生と一緒に考えるた めには, 指導者と学生の良好な関係性の構築が重要であ るといえる。

臨床経験年数による理想像の差が 5 語で認められたこ とより, 臨床経験年数により相違した部分が存在するこ とが示された，経験年数が少ない層（A 群）では，「考 える」,「一緒」が有意に高く, 学生と同じような視点で 問題を解決することを理想としていることが考えられ る。また，有意差は認められなかったが，「楽しさ」も 高い傾向であった. クラスター分析の結果と同様に, 臨 床の楽しさを伝える指導者を理想としていることも考え られた。中堅層（B 群， C 群) では,「合わせる」が有 意に高く, 学生を十分把握したうえで能力に応じた指導 を理想としていることが示唆された. ベテラン層（D群） では，「学生」が有意に高かった。回答の文面から，「学 生の能力把握」, 「学生の成長」という表現が多く, 学生 のことを把握し, 成長させる指導者を理想としているこ
とが推察された。今回の結果から, 臨床経験年数別の理 想像の差を捉えたことで, 指導者の特徴をより詳しく分 析することができた

実習中，学生は指導者の姿から様々なことを学んでい る。言葉遣いや対象者への説明方法, 姿勢や態度など指 導者自身が学生から評価されていることにも気づかなけ ればならない，学生から指導者自身が理学療法士の理想 像として思ってもらえるように理学療法士かつ指導者と して内省し, 共に成長する意識が必要であり, 適切な指 導ができる指導者になるための自己研鑽を行うべきであ る。また，指導者は学生を指導することと同時に養成校 と積極的な連携をとり，ともに理学療法士を育成してい ることに責任を持つことが求められる。一方，実習施設 や指導者によっては, 指導内容や質などが異なり, 学生 が得られるものに相違が生じる場合がある。そのため, 指導者は共通した認識，態度で指導を行うべきである.

本研究の限界として, 一部地域の理学療法士を対象と した調査であり，全国傾向に関する言及が困難であるこ とが挙げられる。 今後は, 全国の理学療法士を対象とし た調査が必要と考える。また, 理想像に関する継続した 意識調査を行うことで, 指導者の在り方を確立していく 必要がある。

本論文の一部を第 52 回日本理学療法学術大会 2017 の発表で用いた。

利益相反 本研究において開示すべき利益相反はない.

謝辞 本研究の実施にあたり，質問紙調査にご協力頂い た皆様に深謝いたします。

\section{引用文献}

1) 社団法人日本理学療法士協会 : 臨床実習教育の手引き, 第 5版. 日本理学療法士協会, 東京, 2007, pp8-16.

2) 中本隆幸:臨床実習指導者が考えておくこと．理学療法京都， 2014, 43: 82-91.

3) 柴田拓哉：臨床実習指導者に必要なスキル，理学療法京都， 2013, 42: 18-21.

4) 北村俊則, 鈴木忠治：社会的望ましさ尺度 日本語版 Sosial Desirability Scaleについて. 社会精神医学, 1986, 9: 173-180.

5) 諸橋 勇 : 臨床実習指導におけるコーチングスキルの応用. 理学療法学, 2011, 38: 397-401.

6) 木村貞治: 臨床実習指導の要点. 理学療法研究. 長野, 2012, 40: 34-43.

7) 小林 賢: 臨床実習指導者からみた臨床実習教育の実態と 展望. PTジャーナル，2014, 48: 481-486.

8) 奈良 勲: 理学療法学教育における臨床実習のあり方を問 う. 広大保健学ジャーナル, 2004, 4: 1-5.

9) 杉本大貴: 学生からみた臨床実習教育の実態と展望. PT ジャーナル, 2014, 48: 487-492. 